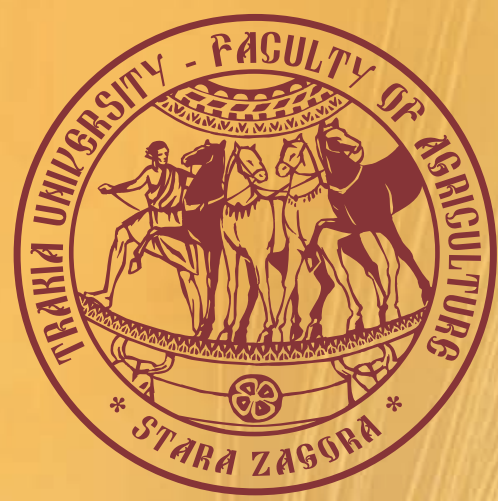

ISSN $1313-8820$ (print)

ISSN $1314-412 X$ (online)

Volume 9 , Number 1

March 2017

\title{
AGRICULTURAL
}

\section{SCIENCE AND TECHNOLOGY}

\section{7}

An International Journal Published by Faculty of Agriculture, Trakia University, Stara Zagora, Bulgaria 


\section{Editor-in-Chief}

Georgi Petkov

Faculty of Agriculture

Trakia University, Stara Zagora

Bulgaria

E-mail: gpetkov@af.uni.sz.bg

\section{Co-Editor-in-Chief}

Dimitar Panayotov

Faculty of Agriculture

Trakia University, Stara Zagora

Bulgaria

\section{Editors and Sections}

\section{Genetics and Breeding}

Tsanko Yablanski (Bulgaria)

Atanas Atanasov (Bulgaria)

Svetlana Georgieva (Bulgaria)

Nikolay Tsenov (Bulgaria)

Max Rothschild (USA)

Ihsan Soysal (Turkey)

Horia Grosu (Romania)

Stoicho Metodiev (Bulgaria)

Bojin Bojinov (Bulgaria)

\section{Nutrition and Physiology}

Nikolai Todorov (Bulgaria)

Peter Surai (UK)

Ivan Varlyakov (Bulgaria)

George Zervas (Greece)

Vasil Pirgozliev (UK)

\section{Production Systems}

Radoslav Slavov (Bulgaria)

Dimitar Pavlov (Bulgaria)

Bogdan Szostak (Poland)

Banko Banev (Bulgaria)

Georgy Zhelyazkov (Bulgaria)

\section{Agriculture and Environment}

Martin Banov (Bulgaria)

Peter Cornish (Australia)

Vladislav Popov (Bulgaria)

Tarek Moussa (Egypt)

\section{Product Quality and Safety}

Stefan Denev (Bulgaria)

Vasil Atanasov (Bulgaria)

Roumiana Tsenkova (Japan)

\section{English Editor}

Yanka Ivanova (Bulgaria)
Scope and policy of the journal

Agricultural Science and Technology /AST/

- an International Scientific Journal of Agricultural and Technology Sciences is published in English in one volume of 4 issues per year, as a printed journal and in electronic form. The policy of the journal is to publish original papers, reviews and short communications covering the aspects of agriculture related with life sciences and modern technologies. It will offer opportunities to address the global needs relating to food and environment, health, exploit the technology to provide innovative products and sustainable development. Papers will be considered in aspects of both fundamental and applied science in the areas of Genetics and Breeding, Nutrition and Physiology, Production Systems, Agriculture and Environment and Product Quality and Safety. Other categories closely related to the above topics could be considered by the editors. The detailed information of the journal is available at the website. Proceedings of scientific meetings and conference reports will be considered for special issues.

\section{Submission of Manuscripts}

There are no submission / handling / publication charges.

All manuscripts written in English should be submitted as MS-Word file attachments via e-mail to editoffice@agriscitech.eu. Manuscripts must be prepared strictly in accordance with the detailed instructions for authors at the website

www.agriscitech.eu and the instructions on the last page of the journal. For each manuscript the signatures of all authors are needed confirming their consent to publish it and to nominate on author for correspondence.

They have to be presented by a submission letter signed by all authors. The form of the submission letter is available upon from request from the Technical Assistance or could be downloaded from the website of the journal. Manuscripts submitted to this journal are considered if they have submitted only to it, they have not been published already, nor are they under consideration for publication in press elsewhere. All manuscripts are subject to editorial review and the editors reserve the right to improve style and return the paper for rewriting to the authors, if necessary. The editorial board reserves rights to reject manuscripts based on priorities and space availability in the journal.

The journal is committed to respect high standards of ethics in the editing and reviewing process and malpractice statement. Commitments of authors related to authorship are also very important for a high standard of ethics and publishing. We follow closely the Committee on Publication Ethics (COPE), http://publicationethics.org/resources/guid elines

The articles appearing in this journal are indexed and abstracted in: DOI, EBSCO Publishing Inc. and AGRIS (FAO).

The journal is accepted to be indexed with the support of a project № BG051PO0013.3.05-0001 "Science and business" financed by Operational Programme "Human Resources Development" of EU. The title has been suggested to be included in SCOPUS (Elsevier) and Electronic Journals Submission Form (Thomson Reuters).

The journal is freely available without charge to the user or his/her institution. Users can read, download, copy, distribute, print, search, or link to the full texts of the articles, or use them for any other lawful purpose, without asking prior permission from the publisher or the author.

This issue is printed with the financial support by Contract No DNP 0521/20.12.2016, financed from Fund 'Scientific Research' grant Bulgarian scientific Periodicals.

\section{Address of Editorial office:}

Agricultural Science and Technology Faculty of Agriculture, Trakia University

Student's campus, 6000 Stara Zagora

Bulgaria

Telephone: +35942699330 $+35942699446$

www.agriscitech.eu

Technical Assistance:

Nely Tsvetanova

Telephone: +359 42699446

E-mail:editoffice@agriscitech.eu 


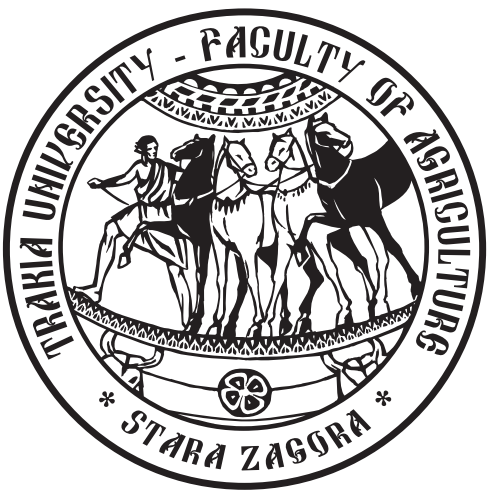

AGRICULTURAL

SCIENCE AND TECHNOLOGY

\section{7}

An International Journal Published by Faculty of Agriculture,

Trakia University, Stara Zagora, Bulgaria 


\title{
Productivity of common wheat (Triticum aestivum L.) grown after various predecessors and nitrogen fertilization rates
}

\author{
M. Gerdzhikova* \\ Department of Plant Growing, Faculty of Agriculture, Trakia University, 6000 Stara Zagora, Bulgaria
}

(Manuscript received 12 December 2016; accepted for publication 20 February 2017)

\begin{abstract}
During the period 2008-2011 the influence of the predecessors wintering peas, spring peas, sunflower and common wheat and different levels of nitrogen fertilization: $0\left(N_{0}\right), 40\left(N_{40}\right), 80\left(N_{80}\right), 120\left(N_{120}\right) \mathrm{kg} / \mathrm{ha}$ after legumes and $0\left(N_{0}\right), 60\left(N_{60}\right), 120\left(N_{120}\right), 180\left(N_{180}\right) \mathrm{kg} / \mathrm{ha}$ after the other predecessors on the productivity of common wheat was studied on the experimental field of the Department of Plant Growing, Trakia University. It was found that with cultivation of common wheat without fertilization after legume predecessors higher yields by $9.4 \%$ were obtained compared to the other predecessors. The highest yields were obtained at fertilization with the highest nitrogen rates: after legume predecessors $4069.8 \mathrm{~kg} / \mathrm{ha} \mathrm{grain}$; after sunflower and wheat $3853.2 \mathrm{~kg} / \mathrm{ha}$ of grain. The strongest influence on the productivity of common wheat had nitrogen fertilization as a factor with $79.80 \%$. The yield of wheat grain correlates very well with the level of nitrogen fertilization and can be determined approximately by regression equations based on the quantity of nitrogen as an independent variable.
\end{abstract}

Keywords: common wheat, productivity, predecessors, nitrogen fertilization

\section{Introduction}

A number of authors have made research on the effect of various stages in the growing technology on the productivity and quality of common wheat grain. The influence of nitrogen fertilization, tillage and predecessors are studied by Angus and Fischer (1991), Anderson (2008), Rieger et al. (2008), He et al. (2009), Dogan and Bilgili (2010). The application of leaf microfertilizers during wheat vegetation increases grain number and grain mass per ear as also increases the crude protein content in grain (Stoyanova and Petkova, 2010). The combined use of liquid leaf fertilizers Wuxal microplant and Codice have increased grain yield by $69.7 \%$ (Stoyanova, 2008). Mineral fertilization with $\mathrm{N}_{22} \mathrm{P}_{20} \mathrm{~K}_{16}$ $\mathrm{kg} / \mathrm{da}$ total for the crop rotation unit corn - wheat increases crude protein yield by $75.5 \%$ on average, and fodder units by $51.6 \%$ on average compared to the non-fertilized controls (Bazitov et al., 2013). The effect of some mixed fertilizers on the productivity and quality of the durum wheat has been established by Delchev et al. (2006) and Delchev (2007).

The influence of predecessors and fertilization on yield and grain quality at different varieties of common wheat is studied in Dobrudzha region - Northeast Bulgaria (Ivanova et al., 2009; Ivanova et al., 2010; Ivanova and Tsenov, 2012) and in Southeast Bulgaria (Delibaltova, 2008; Delibaltova et al., 2010; Delibaltova and Kirchev, 2016). According to Ivanova and Tsenov (2012), the positive effect of leguminous predecessor is well expressed under conditions of drought. The productivity of wheat decreased with only $9 \%$ after predecessor bean and with $21-25 \%$ after a fodder maize, sunflower and grain maize. According to Delibaltova (2008), Delibaltova and Kirchev (2016) the most suitable predecessor for common wheat under the conditions of Southeast Bulgaria is coriander. After it is realized with $3.6 \%$ and $6.8 \%$ higher yield

*e-mail: m_gerdjikova@abv.bg compared with predecessors sunflower and barley. Wheat planted after oilseed rape have significantly higher shoot biomass and grain yield than wheat planted after maize (Rieger et al., 2008). The effect of various herbicides and herbicide combinations on the productivity of several common wheat varieties has been found in Stara Zagora region, South Central Bulgaria by Georgiev (2014), Stoyanova and Georgiev (2014). Under the same conditions the effect of predecessors and nitrogen fertilization in triticale has been found by Gerdzhikova (2015). The effect of various predecessors and the simultaneous impact of different levels of nitrogen fertilization on the productivity of wheat has not been studied in this region. That is the purpose of the present study.

\section{Material and methods}

The experiment was conducted on the experimental field of the Department of Plant Growing, Trakia University during the period 2008-2011. The study is set out using a block method in 4 replicates with test plot size of $20 \mathrm{~m}^{2}$ and reported plot of size $10 \mathrm{~m}^{2}$. Common wheat, Diamant varietry, was grown after predecessors: wintering peas, spring peas, sunflower and common wheat. The following levels of nitrogen fertilization were applied: $0\left(\mathrm{~N}_{0}\right), 40\left(\mathrm{~N}_{40}\right), 80\left(\mathrm{~N}_{80}\right)$, $120\left(N_{120}\right) \mathrm{kg} / \mathrm{ha}$ after wintering peas and spring peas and $0\left(\mathrm{~N}_{0}\right), 60$ $\left(\mathrm{N}_{60}\right), 120\left(\mathrm{~N}_{120}\right), 180\left(\mathrm{~N}_{180}\right) \mathrm{kg} / \mathrm{ha}$ after sunflower and common wheat. The crops were grown without irrigation under conventional production systems. The soil is typically meadow cinnamon. In the layer $0-30 \mathrm{~cm}$ humus content is $1.55 \%$. The soil is poorly stocked with nitrogen and phosphorus and well stocked with potassium. The reaction is slightly acidic to neutral.

The data were processed statistically by ANOVA with Statistics 6 for Windows. 


\section{Results and discussion}

Heat conditions during the three vegetation periods in which wheat was grown - 2008-2009, 2009-2010, 2010-2011 were with average air temperature $9.8^{\circ} \mathrm{C}, 9.8^{\circ} \mathrm{C}, 9.5^{\circ} \mathrm{C}$, respectively, slightly higher than average for the period $1953-2007\left(9.1^{\circ} \mathrm{C}\right)$ (Figure 1). November and December were with higher temperatures during the study period. In January lower average monthly temperatures were recorded in 2009 and 2010 by $0.8^{\circ} \mathrm{C}$ and $0.2{ }^{\circ} \mathrm{C}$, respectively. Spring months were with temperatures close to the typical for the region. Warmer than the average for the region were May and June. Differences ranged from $0.2^{\circ} \mathrm{C}$ to $1.4^{\circ} \mathrm{C}$ in May and from $0.3^{\circ} \mathrm{C}$ to $1.3^{\circ} \mathrm{C}$ in June. In terms of precipitation the most favorable was the vegetation period 2009-2010 with rainfall amount $535.4 \mathrm{~mm}$ - by $30.1 \%$ higher than the average for the period 1953-2007. The most unfavorable was the vegetation period 2010-2011 with an amount of precipitation $33.6 \%$ lower than the average, while in 2008-2009 it was $21.7 \%$ lower. The distribution of rainfall in 2008-2009 and 20102011 was uneven and can be expected to have an impact on wheat productivity.

Climatic conditions vary during the years of the study, which is reflected on the influence of the studied factors on wheat productivity as well. The most favorable were the conditions during the vegetation period of vintage year 2010. In the variants without fertilization yields ranged from $2810.5 \mathrm{~kg} / \mathrm{ha}$ after predecessor wheat to $3096.0 \mathrm{~kg} / \mathrm{ha}$ after wintering peas (Table 1). The lowest were the yields in vintage year 2011, when during stages of stem elongation, ear emergence and flowering rainfall was below the normal for the region. Grain yield in the variants without nitrogen fertilization varied from $2317.5 \mathrm{~kg} / \mathrm{ha}$ after predecessor wheat to $2625.0 \mathrm{~kg} / \mathrm{ha}$ after wintering peas. Grain yields in 2009 occupy an intermediate position with values in variants without nitrogen fertilization from $2415.8 \mathrm{~kg} / \mathrm{ha}$ after wheat to $2828.0 \mathrm{~kg} / \mathrm{ha}$ after predecessor spring peas. On average for the study period yields were from $2514.6 \mathrm{~kg} / \mathrm{ha}$ after wheat to $2839.8 \mathrm{~kg} / \mathrm{ha}$ after wintering peas.
Legume predecessors have positive effect on wheat grain yield. And all three years of the experiment, after wintering and spring peas in variants without fertilization higher yields of grain were obtained on average compared to the average values of these variants after sunflower and wheat, by $269.2 \mathrm{~kg} / \mathrm{ha}(10.6 \%)$ in $2009,208.8 \mathrm{~kg} / \mathrm{ha}$ $(7.3 \%)$ in $2010,248.8 \mathrm{~kg} / \mathrm{ha}(10.5 \%)$ in 2011 , respectively. On average for the study period grain yield was by $242.3 \mathrm{~kg} / \mathrm{ha}(9.4 \%)$ higher after legume predecessors. Similar results are obtained by Anderson (2008) and Dogan and Bilgili (2010).

The application of increasing nitrogen fertilization rates leads to increased grain yields after all predecessors and in each year of the study. In fertilization with the highest nitrogen rates the highest yield is obtained. Compared to the non-fertilized variant the relative increase in yield by years and predecessors was as follows:

- After wintering peas and fertilizing with $\mathrm{N}_{120}-43.3 \%$ in the vintage year $2009,38.6 \%$ in 2010 and $46.1 \%$ in 2011 , average for the study period $-42.5 \%$.

- After spring peas and fertilizing with $\mathrm{N}_{120}$ - from $42.0 \%$ to $49.9 \%$, an average of $44.9 \%$.

- After sunflower and fertilization with $\mathrm{N}_{180}$ - from $42.8 \%$ to $53.5 \%$, an average of $47.0 \%$.

- After common wheat and fertilization with $\mathrm{N}_{180}$ - from $41.5 \%$ to $56.5 \%$, an average of $50.6 \%$.

The most effective nitrogen fertilizer rates established by other researchers are 120-160 kg/ha (Angus and Fischer, 1991; Delibaltova, 2008; Rieger et al., 2008; He et al., 2009; Dogan and Bilgili, 2010; Delibaltova and Kirchev, 2016).

Although the highest yields of wheat grain are obtained by fertilization with the highest nitrogen fertilizer rate, the determining of the optimal rate can be done by comparing the different levels of fertilization. The average grain yield after legume predecessors for the study period without nitrogen fertilization was $2832.8 \mathrm{~kg} / \mathrm{ha}$. In fertilization with $40 \mathrm{~kg} / \mathrm{ha}$ of nitrogen, yield increased by $304.2 \mathrm{~kg} / \mathrm{ha}$ or $10.7 \%$, while in fertilization with $80 \mathrm{~kg} / \mathrm{ha}$ of nitrogen, grain yield compared to $\mathrm{N}_{0}$ increased by $921.3 \mathrm{~kg} / \mathrm{ha}$ - $(32.5 \%)$. The increase compared to the previous nitrogen rate was with $617.1 \mathrm{~kg} / \mathrm{ha}$ grain -

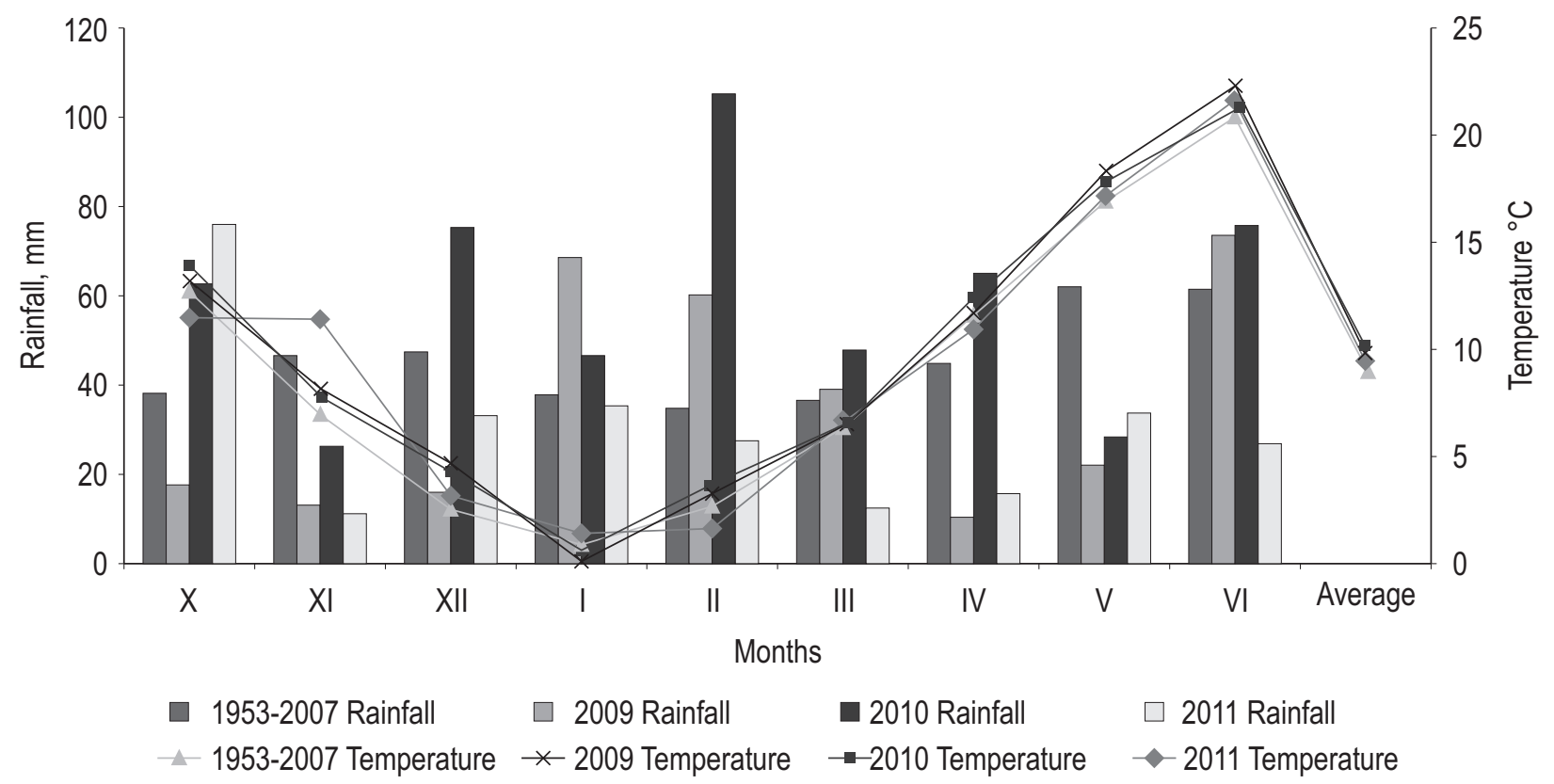

Figure 1. Temperature and rainfall conditions in the vegetation of common wheat for the study period (2008-2011) and the period 1953-2007 
Table 1. Grain yield of common wheat after various predecessors and nitrogen fertilization rates by years and average for the period 2009-2011, kg/ha

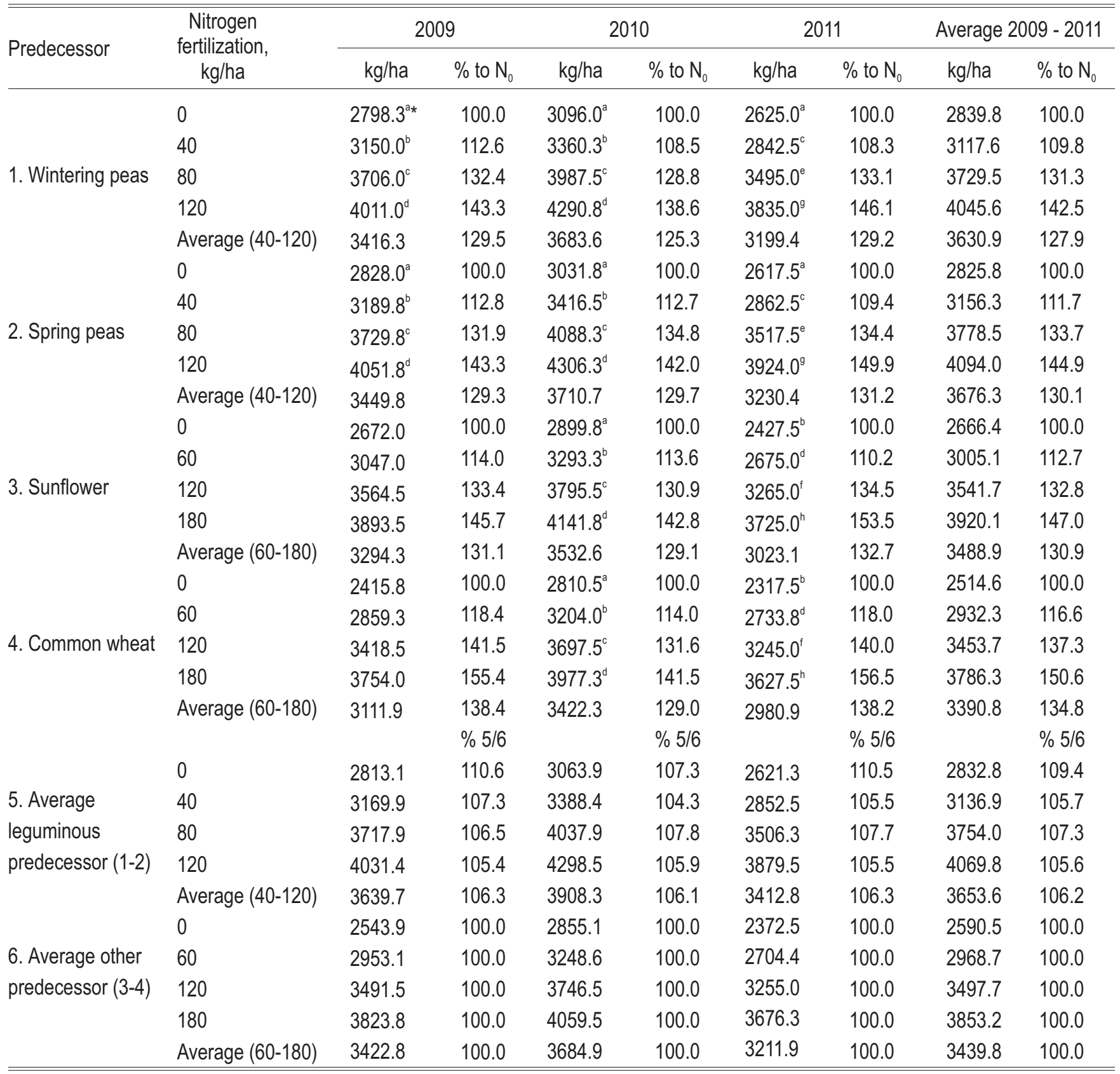

* The differences in yields between the variants are statistically proven at $\mathrm{P}<0.05$ if not identical letters

$19.7 \%$. When fertilizing with $120 \mathrm{~kg} / \mathrm{ha}$ yield increased by $1237 \mathrm{~kg} / \mathrm{ha}$ grain $-43.7 \%$, but compared to the previous level of fertilization $\left(\mathrm{N}_{80}\right)$ the increase was with $315.8 \mathrm{~kg} / \mathrm{ha}$, i.e. by $8.4 \%$, compared to fertilization with $40 \mathrm{~kg} / \mathrm{ha}-932.9 \mathrm{~kg} / \mathrm{ha}(29.7 \%)$.

The average grain yield after predecessors sunflower and common wheat for the study period without fertilization with nitrogen was with $2590.5 \mathrm{~kg} / \mathrm{ha}$. In fertilization with $60 \mathrm{~kg} / \mathrm{ha}$ of nitrogen yield increased by $378.2 \mathrm{~kg} / \mathrm{ha}$ or $14.6 \%$, in fertilizing with $120 \mathrm{~kg} / \mathrm{ha}$ of nitrogen grain yield compared to $\mathrm{N}_{0}$ increased by $907.2 \mathrm{~kg} / \mathrm{ha}$ $35.0 \%$. The increase compared to the previous nitrogen rate was with $529 \mathrm{~kg} / \mathrm{ha}$ grain $-17.8 \%$. In fertilizing with $180 \mathrm{~kg} / \mathrm{ha}$ yield increased by $1262.7 \mathrm{~kg} / \mathrm{ha}$ grain compared to $\mathrm{N}_{0}-48.4 \%$, but compared to the previous fertilization level the increase was with $355.5 \mathrm{~kg} / \mathrm{ha}$, i.e. by $10.2 \%$, compared to fertilization with $60 \mathrm{~kg} / \mathrm{ha}-$
$884.5 \mathrm{~kg} / \mathrm{ha}(29.8 \%)$.

The level of proof of differences in wheat grain yield under the influence of predecessors and the level of nitrogen fertilization was different from year to year. In 2009 after legume predecessors differences in wheat grain yields between the nitrogen fertilization levels are statistically proved at $P<0.05$, but the differences between the same nitrogen fertilization levels after wintering and spring peas are not statistically proved. While growing wheat after predecessors wheat and sunflower differences are shown between the different levels of nitrogen fertilization and at the same level of fertilization. That confirms the lower productivity of wheat after nonleguminous predecessors sunflower and wheat.

In 2010 differences in grain yield between nitrogen fertilization levels are statistically proved at $\mathrm{P}<0.05$, but the differences 
Table 2. Degree of influence of factors on wheat grain yield, \%

\begin{tabular}{lrrrrrr}
\hline \hline Factor & \multicolumn{1}{c}{ SS } & DF & MS & \multicolumn{1}{c}{ F } & \multicolumn{1}{c}{ P } & \multicolumn{1}{c}{$\%$} \\
\hline Predecessor & 2662563 & 3 & 887521 & 120.0 & 0.0001 & 4.68 \\
Year & 7375244 & 2 & 3687622 & 498.7 & 0.0001 & 12.97 \\
N fertilization & 45372090 & 3 & 15124030 & 2045.5 & 0.0001 & 79.80 \\
Predecessor*Year & 81186 & 6 & 13531 & 1.8 & 0.0972 & 0.14 \\
Predecessor*N fertilization & 95409 & 9 & 10601 & 1.4 & 0.1789 & 0.17 \\
Year*N fertilization & 117536 & 6 & 19589 & 2.6 & 0.0182 & 0.21 \\
Predecessor*Year* N fertilization & 91687 & 18 & 5094 & 0.7 & 0.8179 & 0.16 \\
Error & 1064733 & 144 & 7394 & & & 1.87 \\
\hline \hline
\end{tabular}

Table 3. Regression equations for determining common wheat grain yield after various predecessors depending on the level of nitrogen fertilization

\begin{tabular}{|c|c|c|c|c|c|}
\hline Predecessor & Equation & ${ }^{*} R^{2}$ & SEE & $\mathrm{F}$ & $P$ \\
\hline \multicolumn{6}{|c|}{ Nitrogen fertilization $-0,40,80,120 \mathrm{~kg} / \mathrm{ha}$} \\
\hline Wintering peas & $Y=2808.254+9.856 \mathrm{~N}+0.006 \mathrm{~N}^{2}$ & 0.810 & 66.6 & 95.8 & 0.001 \\
\hline Spring peas & $Y=2795.825+11.349 \mathrm{~N}-0.002 \mathrm{~N}^{2}$ & 0.836 & 63.7 & 114.8 & 0.001 \\
\hline \multicolumn{6}{|c|}{ Nitrogen fertilization - 0,60, 120, $180 \mathrm{~kg} / \mathrm{ha}$} \\
\hline Sunflower & $Y=2648.612+6.665 \mathrm{~N}+0.003 \mathrm{~N}^{2}$ & 0.822 & 65.0 & 103.8 & 0.001 \\
\hline Common wheat & $Y=2499.966+8.291 \mathrm{~N}-0.006 \mathrm{~N}^{2}$ & 0.844 & 60.5 & 122.3 & 0.001 \\
\hline
\end{tabular}

$* \mathrm{R}^{2}$ - Coefficient of determination, SEE - Standard error, $\mathrm{F}$ - Ratio, $\mathrm{P}$ - Statistical significance of the equation, $\mathrm{Y}-\mathrm{Common}$ wheat grain yield, $\mathrm{kg} / \mathrm{ha}, \mathrm{N}-$ Nitrogen fertilization, $\mathrm{kg} / \mathrm{ha}$

between the same levels of nitrogen fertilization are not statistically proved after legumes and after sunflower and wheat.

In 2011 differences in grain yield of wheat between the same levels of nitrogen fertilization after wintering and spring peas and after sunflower and wheat are not statistically proved. The differences at the same levels of fertilization are proved between leguminous and non-leguminous predecessors.

The analysis of the level of impact of factors on grain yield (Table 2) proved that nitrogen fertilization had the greatest effect on that parameter by $79.80 \%$. Next in importance are the conditions throughout the years of conducting the experiment by $12.97 \%$. Third is the impact of the predecessor $-4.68 \%$. The level of proving of the factors is very high $p<0.001$.

Productivity of common wheat grown after various predecessors and levels of nitrogen fertilization correlates very well to the amount of nitrogen input. That allows to determine in advance grain yields by regression equations based on nitrogen input as an independent variable within the specified range about nitrogen fertilization level depending on the type of predecessor (Table 3 ).

The determination coefficient $R^{2}$ varies from 0.810 to 0.844 . It is high enough and shows that the link between wheat grain yield and nitrogen fertilization is very good. In that way through a second order polynomial yields can be determined with good accuracy. All equations have very high level of statistical reliability. This allows to use them in the practice for approximate determination of grain yield.

\section{Conclusion}

The highest grain yields of common wheat (after legume predecessors wintering and spring pea - $4069.8 \mathrm{~kg} / \mathrm{ha}$; after sunflower and wheat $-3853.2 \mathrm{~kg} / \mathrm{ha}$ ) are obtained by fertilization with the highest applied nitrogen rates $\left(\mathrm{N}_{120}\right.$ and $\left.\mathrm{N}_{180}\right)$. In growing common wheat without fertilization after legume predecessors $9.4 \%$ higher yields are obtained in comparison with the other predecessors. In growing wheat after grain predecessor, optimum yield is obtained by fertilization with $80 \mathrm{~kg} / \mathrm{ha}$ nitrogen and after another predecessor - with $120 \mathrm{~kg} / \mathrm{ha}$ nitrogen. On the productivity of common wheat the greatest influence is exerted by nitrogen fertilization as a factor of $79.80 \%$. The impact of the year is $12.97 \%$ and of the predecessor $-4.68 \%$. Wheat grain yield correlates very well with the level of nitrogen fertilization and can be approximately determined by regression equations based on the quantity of imported nitrogen as an independent variable.

\section{References}

Anderson R, 2008. Growth and Yield of Winter Wheat as Affected by Preceding Crop and Crop Management. Agronomy Journal, 100, 977-980

Angus J and Fischer R, 1991. Grain protein responses to nitrogen applied to wheat growing on a red earth. Crop and Pasture Science, 42, 735-746.

Bazitov R, Vasilev V and Bazitov V, 2013. Productivity of crop rotation link corn - wheat depending on some factors agrotechnical. Science \& Technologies, III, 195-198 (Bg).

Delchev Gr, 2007. Changes in photosynthetic activity and productivity of durum wheat under the influence of some mixed fertilizers. Coll. "Plant gene pool - the basis of modern agriculture", Sadovo, 3, 559-562(Bg).

Delchev Gr, Kolev T and Zhelyazkova Ts, 2006. Influence of some mixed min ral fertilizers in combination with foliar feeding on the grain yield and grain quality of the durum wheat. Safe food, Novi Sad, I, 
255-260.

Delibaltova V, 2008. Investigation of the predecessor and fertilization influence on the productivity of winter wheat variety Aglika. Plant Science, 45, 437-441 (Bg).

Delibaltova V and Kirchev H, 2016. Productivity of common wheat (Triticum aestivum L.) depending on predecessor and the level of nitrogen fertilization. International Journal for Research in Agricultural Research, 1, 1-10.

Delibaltova V, Zhelyazkov I and Kirchev H, 2010. Influence of predecessor and norms of nitrogen fertilization on grain quality of winter wheat variety Prelom. Plant Science, 47,434-440 (Bg).

Dogan R and Bilgili U, 2010. Effects of previous crop and Nfertilization on seed yield of winter wheat (Triticum aestivum L.) under rainfed Mediterranean conditions. Bulgarian Journal of Agricultural Science, 16, 733-739.

Georgiev M, 2014. Influence of some herbicides and herbicide combinations on yield and harvest index in common wheat "Diamond" variety. Science \& Technologies, IV, 280-286 (Bg).

Gerdzhikova M, 2015. Influence of some predecessors and nitrogen fertilization on the productivity, chemical composition and nutritive value of triticale ( $\times$ Triticosecale Wittm.) in the region of Stara Zagora. Thesis for PhD, Trakia University, Stara Zagora (Bg).

He P, Li S, Jin J, Wang H, Li C, Wang Y and Cui R, 2009. Performance of an Optimized Nutrient Management System for Double-Cropped Wheat-Maize Rotations in North-Central China. Agronomy Journal, 101, 1489-1496.
Ivanova A, Nankova M, Tsenov N and Kirchev H, 2009. Effect of some agronomy factors on the productivity of variety Aglika (Triticum aestivum L.) in Dobrudzha region. International Conference "Lakes and Nutrient Loads" Alblakes, Proceedings, Pogradec, 24-26 April, 249-255.

Ivanova A and Tsenov N, 2012. Winter Wheat Productivity under Favorable and Drought Environments. II. Effect of Previous Crop. Bulgarian Journal of Agricultural Science, 18, 29-35.

Ivanova A, Tsenov $\mathbf{N}$ and Kirchev H, 2010. Impact of environment and some agronomy practices on the productivity of the new wheat variety Bolyarka in South Dobrudzha region. BALWOIS 2010 Ohrid, Republic of Macedonia, II.

Rieger S, Richner W, Streit B, Frossard E and Liedgens M, 2008. Growth, yield and yield components of winter wheat and the effects of tillage intensity, preceding crops and $\mathrm{N}$ fertilization. European Journal Agronomy, 28, 405-411.

Stoyanova A, 2008. Influence of some foliar fertilizers on the productivity of wheat. Collection of Scientific Conference, Kardzhali, 267-271 (Bg)

Stoyanova A and Georgiev M, 2014. Influence of some herbicides and herbicide combinations on the productive capacity of six varieties of common wheat. Science \& Technologies, IV, 6, 77-87 (Bg).

Stoyanova A and Petkova R, 2010. Structure of yield and quality of wheat grain treated with foliar fertilizers. Plant Science, 1, 36-41 (Bg). 


\section{Review}

Antimicrobial activity of Lactobacillus acidophilus against pathogenic and food spoilage microorganisms: A review

T. Dinev, G. Beev, S. Denev, D. Dermendzhieva, M. Tzanova, E. Valkova

\section{Genetics and Breeding}

Heterosis and degrees of dominance of grain yield and grain yield elements in maize hybrids in different groups of ripeness

M. Ilchovska

Use of recurrent selection of early flowering in late maize synthetic population. Results of second cycle of breeding.

N. Petrovska, V. Valkova

Productivity and adaptability of new genotypes field pea (Pisum sativum L.) cultivated under environmental condition of Southern Romania

R. Sturzu, A. M. Ene, Cr. Melucă, J. M. Cojocaru

Nitrogen uptake and expense in durum wheat depending on genotype and nitrogen fertilization

G. Panayotova, M. Almaliev, S. Kostadinova

\section{Nutrition and Physiology}

Haematological investigations upon acute intoxication with carbofuran in dogs

R. Binev, I. Valchev, R. Russenov, Y. Nikolov

\section{Production Systems}

Phytosanitary status and yield of kamut (Triticum turgidum polonicum L.) grown in organic and biodynamic farming

V. Maneva, D. Atanasova, T. Nedelcheva

Hot-water treatment of gladiolus cormels for control of corm-borne fungal diseases

S. Bistrichanov, T. Vatchev, Z. Avramov

Productivity of common wheat (Triticum aestivum L.) grown after various predecessors and nitrogen fertilization rates

M. Gerdzhikova

\section{Agriculture and Environment}


Screening of cucurbitaceous rootstocks against root-knot nematodes (Meloidogyne spp.) and soilborne pathogens (Fusarium spp. and Pythium spp.)

V. Yankova, D. Markova, N. Velkov, S. Masheva

Animal hygiene assessment of microclimate in semi open free-stall barns for dairy cows

D. Dimov, Ch. Miteva, I. Marinov, Zh. Gergovska, T. Penev, A. Enchev

Product Quality and Safety

Accumulation of astaxanthin and canthaxanthin in muscle tissues of Rainbow trout (Oncorhynchus mykiss W.) fed with xanthophyll supplemented feed

M. Tzanova

Chemical composition and technological characteristics of wines from red grape varieties, selected in Bulgaria

V. Haygarov, T. Yoncheva, Z. Nakov, M. Ivanov, D. Dimitrov 


\section{Instruction for authors}

\section{Preparation of papers}

Papers shall be submitted at the editorial office typed on standard typing pages (A4, 30 lines per page, 62 characters per line). The editors recommend up to 15 pages for full research paper ( including abstract references, tables, figures and other appendices)

The manuscript should be structured as follows: Title, Names of authors and affiliation address, Abstract, List of keywords, Introduction, Material and methods, Results, Discussion, Conclusion, Acknowledgements (if any), References, Tables, Figures.

The title needs to be as concise and informative about the nature of research. It should be written with small letter /bold, 14/ without any abbreviations.

Names and affiliation of authors The names of the authors should be presented from the initials of first names followed by the family names. The complete address and name of the institution should be stated next. The affiliation of authors are designated by different signs. For the author who is going to be corresponding by the editorial board and readers, an E-mail address and telephone number should be presented as footnote on the first page. Corresponding author is indicated with *.

Abstract should be not more than 350 words. It should be clearly stated what new findings have been made in the course of research. Abbreviations and references to authors are inadmissible in the summary. It should be understandable without having read the paper and should be in one paragraph.

Keywords: Up to maximum of 5 keywords should be selected not repeating the title but giving the essence of study.

The introduction must answer the following questions: What is known and what is new on the studied issue? What necessitated the research problem, described in the paper? What is your hypothesis and goal?

Material and methods: The objects of research, organization of experiments, chemical analyses, statistical and other methods and conditions applied for the experiments should be described in detail. A criterion of sufficient information is to be possible for others to repeat the experiment in order to verify results.

Results are presented in understandable tables and figures, accompanied by the statistical parameters needed for the evaluation. Data from tables and figures should not be repeated in the text. Tables should be as simple and as few as possible. Each table should have its own explanatory title and to be typed on a separate page. They should be outside the main body of the text and an indication should be given where it should be inserted.

Figures should be sharp with good contrast and rendition. Graphic materials should be preferred. Photographs to be appropriate for printing. Illustrations are supplied in colour as an exception after special agreement with the editorial board and possible payment of extra costs. The figures are to be each in a single file and their location should be given within the text.

Discussion: The objective of this section is to indicate the scientific significance of the study. By comparing the results and conclusions of other scientists the contribution of the study for expanding or modifying existing knowledge is pointed out clearly and convincingly to the reader. Conclusion: The most important consequences for the science and practice resulting from the conducted research should be summarized in a few sentences. The conclusions shouldn't be numbered and no new paragraphs be used. Contributions are the core of conclusions. References:

In the text, references should be cited as follows: single author: Sandberg (2002); two authors: Andersson and Georges (2004); more than two authors: Andersson et al.(2003). When several references are cited simultaneously, they should be ranked by chronological order e.g.: (Sandberg, 2002; Andersson et al., 2003; Andersson and Georges, 2004).

References are arranged alphabetically by the name of the first author. If an author is cited more than once, first his individual publications are given ranked by year, then come publications with one co-author, two co-authors, etc. The names of authors, article and journal titles in the Cyrillic or alphabet different from Latin, should be transliterated into Latin and article titles should be translated into English. The original language of articles and books translated into English is indicated in parenthesis after the bibliographic reference $($ Bulgarian $=\mathrm{Bg}$, Russian $=\mathrm{Ru}$, Serbian $=\mathrm{Sr}$, if in the Cyrillic, Mongolian =
Mo, Greek = Gr, Georgian = Geor., Japanese $=\mathrm{Ja}$, Chinese $=\mathrm{Ch}$, Arabic $=\mathrm{Ar}$, etc.)

The following order in the reference list is recommended:

Journal articles: Author(s) surname and initials, year. Title. Full title of the journal, volume, pages. Example:

Simm G, Lewis RM, Grundy B and Dingwall WS, 2002. Responses to selection for lean growth in sheep. Animal Science, 74, 39-50

Books: Author(s) surname and initials, year. Title. Edition, name of publisher, place of publication. Example:

Oldenbroek JK, 1999. Genebanks and the conservation of farm animal genetic resources, Second edition. DLO Institute for Animal Science and Health, Netherlands.

Book chapter or conference proceedings: Author(s) surname and initials, year. Title. In: Title of the book or of the proceedings followed by the editor(s), volume, pages. Name of publisher, place of publication. Example:

Mauff G, Pulverer G, Operkuch W, Hummel K and Hidden C, 1995. C3variants and diverse phenotypes of unconverted and converted C3. In: Provides of the Biological Fluids (ed. $\mathrm{H}$. Peters), vol. 22, 143-165, Pergamon Press. Oxford, UK.

Todorov N and Mitev J, 1995. Effect of level of feeding during dry period, and body condition score on reproductive performance in dairy cows, $I^{\text {th }}$ International Conference on Production Diseases in Farm Animals, September 11-14, Berlin, Germany.

Thesis:

Hristova D, 2013. Investigation on genetic diversity in local sheep breeds using DNA markers. Thesis for PhD, Trakia University, Stara Zagora, Bulgaria, (Bg).

The Editorial Board of the Journal is not responsible for incorrect quotes of reference sources and the relevant violations of copyrights.

\section{Animal welfare}

Studies performed on experimental animals should be carried out according to internationally recognized guidelines for animal welfare. That should be clearly described in the respective section "Material and methods". 


\section{AGRICULTURAL \\ SCIENCE AND TECHNOLOGY}

Volume 9, Number 1 March 2017
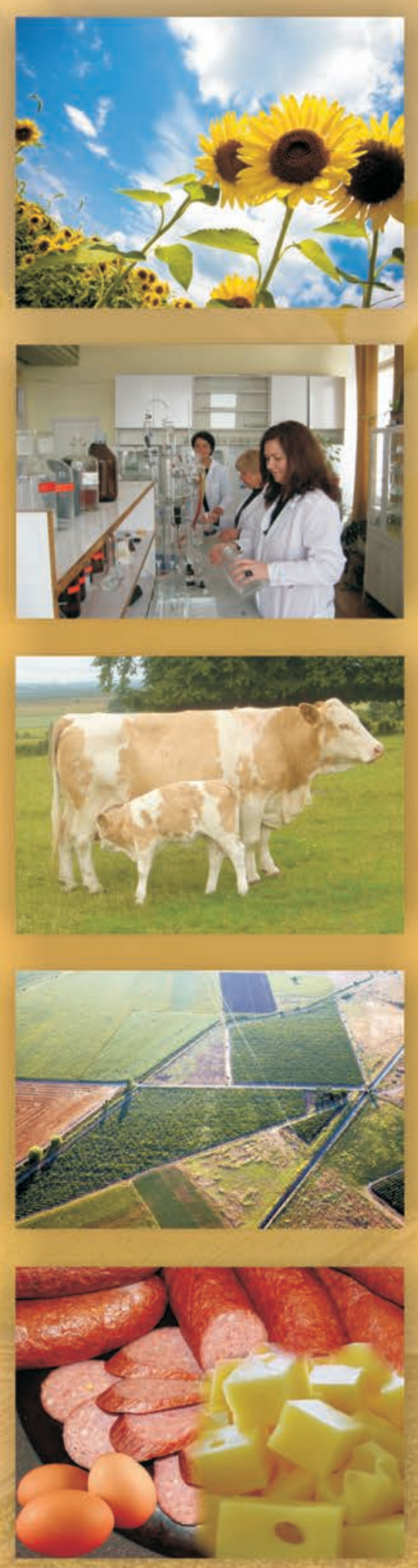

Journal web site: 